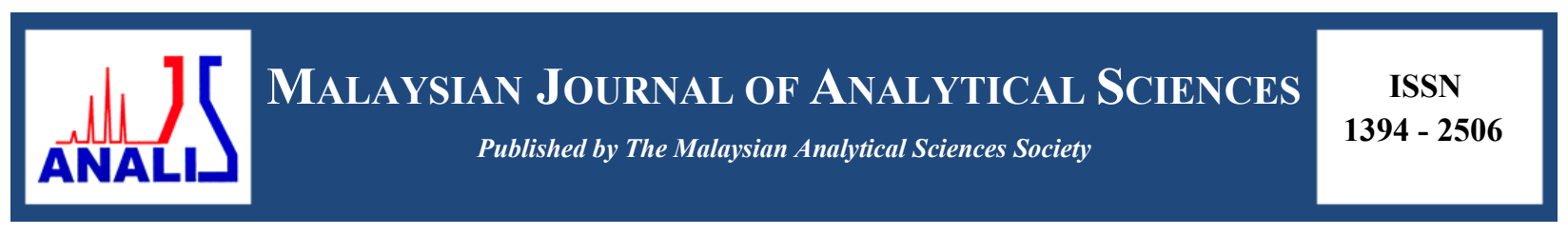

\title{
THREE FLAVONOL GLYCOSIDES FROM Calliandra surinamensis Benth
}

\author{
(Tiga Flavonol Glikosida daripada Calliandra surinamensis Benth) \\ Siti Muhayyah Omar, Norizan Ahmat*, Nik Fatini Nik Azmin \\ Department of Chemistry, Faculty of Applied Sciences, \\ Universiti Teknologi MARA, 40450 Shah Alam, Selangor, Malaysia \\ *Corresponding author: noriz118@salam.uitm.edu.my
}

Received: 24 February 2015; Accepted: 27 October 2015

\begin{abstract}
Calliandra surinamensis or Pinkpowder puff is a tropical shrub, named after Suriname. In Borneo, such as Sarawak and East Kalimantan area, it was known as "daun assam jawa". This species belonging to the family of Leguminosae and subfamily of Mimosoideae originated from tropical America. Calliandra surinamensis has been used in folk medicine to treat various diseases and infections such as cough, wound healing and inflammation. In this study, the flowers of Calliandra surinamensis was extracted by successive extraction. The phytochemical procedures adopted were vacuum liquid chromatography (VLC), and radial chromatography (RC). Phytochemical investigation of Calliandra surinamensis flower afforded three flavonol glycosides identified namely (1) 3-O-rhamnosylkaempferol (2) 3-O-rhamnosylmyricetin and (3) Myricetin-3-O-heptoseptanoside. The molecular structures of the isolated compounds were established based on spectroscopic methods such as $1 \mathrm{D}-\mathrm{NMR}\left({ }^{1} \mathrm{H},{ }^{13} \mathrm{C}\right.$, DEPT) and 2D-NMR (COSY, HMQC, HMBC) and comparison with literature.
\end{abstract}

Keywords: leguminosae, Calliandra surinamensis, 3-o-ramnosilkaempferol, 3-o-ramnosilmyricetin, myricitrin-3-oheptoseptanoside

\begin{abstract}
Abstrak
Calliandra surinamensis atau Pinkpowder puff adalah pokok renek tropika, dinamakan sempena nama Negara Surinam di Utara Amerika Selatan. Di Borneo seperti kawasan Sarawak dan Kalimantan Timur, ia dikenali sebagai "daun asam jawa". Spesies daripada keluarga Leguminosae dan subkeluarga Mimosoideae ini berasal dari Amerika bahagian tropika [4]. Calliandra surinamensis telah digunakan dalam perubatan tradisional untuk merawat pelbagai penyakit dan jangkitan seperti batuk, penyembuhan luka dan keradangan. Melalui kajian ini, bunga - bunga Calliandra surinamensis telah diekstrak melalui pengekstrakkan berturut-turut. Prosedur fitokimia yang digunakan adalah kromatografi cecair vakum (VLC) dan kromatografi jejarian. Kajian fitokimia daripada bunga Calliandra surinamensis telah menghasilkan tiga flavonol glikosida yang dikenalpasti sebagai (1) 3-O-ramnosilkaempferol (2) 3-O-ramnosilmyricetin dan (3) myricetin-3-O-heptoseptanosida. Struktur molekul sebatian terpencil telah dikenalpasti berdasarkan kaedah spektroskopi seperti 1D-NMR $\left({ }^{1} \mathrm{H},{ }^{13} \mathrm{C}, \mathrm{DEPT}\right)$ dan $2 \mathrm{D}-\mathrm{NMR}(\mathrm{COSY}$, HMQC, HMBC) serta perbandingan dengan data literatur.
\end{abstract}

Kata kunci: leguminosae, Calliandra surinamensis, 3-o-rhamnosilkaempferol, 3-o-rhamnosilmyricetin, myricitrin-3-oheptosepta-nosida

\section{Introduction}

The genus Calliandra is one of the largest genera of the Leguminosae (Fabaceae), with approximately 200 species. It grows mostly in the tropical and sub-tropical regions of America with a few native also found in Madagascar and India. Various species in the genus have been reported for the treatment of eye diseases, diarrhea, indigestion [1], 
diabetes and obesity [2]. Previous studies on the phytochemistry of several Calliandra species revealed different classes of compounds such as flavonoids, diterpenes, triterpenes, amino acids and polyphenols.

In the search of biologically active and interesting compounds from plants, the investigation on Calliandra surinamensis was carried out. Calliandra surinamensis locally known in Malaysia as "Kaliandra bunga merah" is a flowering plant endemic to southern Asia, Africa, Australia and America. Previous investigation reported the stem bark was used as traditional medicine by the folklore to treat various diseases and infections, antioxidants and antimicrobial activity [3,4]. The knowledge on isolation of the chemical constituents from this species is still limited. A preliminary study by Falodun and Qiu [5] on the rootbark of the plant reported some secondary metabolites such as flavonoid, $\beta$-sitosterol 3-O- $\beta$-D-glucopyranoside and recursterol. This paper reports on the isolation and structure elucidation of flavonoid compounds from the flower of Calliandra surinamensis which has not been reported before.

\section{Experimental procedures}

\section{Materials and Methods}

The ${ }^{1} \mathrm{H}-\mathrm{NMR}$ and ${ }^{13} \mathrm{C}-\mathrm{NMR}$ spectra were recorded on a Bruker 300 Ultrashield NMR spectrometer (Switzerland) measured at 300 and $75 \mathrm{MHz}$, respectively, using chloroform-D and methanol-D (Merck) as solvent. Chemical shifts are reported in $\delta \mathrm{ppm}$ (part per million) with coupling constants given in Hertz (Hz). The infrared (IR) spectra were recorded using Perkin-Elmer 1600 series FTIR spectrometer (USA) using $\mathrm{KBr}$ pellets. The ultraviolet (UV) spectra were recorded on Shimadzu UV-Vis 160i spectrometer. The mass spectra were measured on Perkin Elmer Clarus 600T spectrometer $70 \mathrm{eV}$. Vacuum liquid chromatography (VLC) used Silica gel 60, 70-230 mesh ASTM (Merck 1.07747), Radial chromatography used Si-gel 60 PF254 (Merck 1.07749). For TLC analysis, pre-coated silica gel plates (Merck Kieselgel 60 GF254 $0.25 \mathrm{~mm}$ ) were used and visualized under UV light [6].

\section{Plant material}

The fresh flowers of Calliandra surinamensis was collected from the Universiti Teknologi MARA Shah Alam, Malaysia in September 2011. Botanical identification was done by a taxonomist Prof. Dr Mohd Nazip Suratman from Faculty of Applied Sciences, Universiti Teknologi MARA, Malaysia.

\section{Extraction and isolation procedure}

The dried powdered of flower (70 grams) of Calliandra surinamensis was defatted in methanol $\left(40{ }^{\circ} \mathrm{C}-60{ }^{\circ} \mathrm{C}\right)$ for 48 hours repeated for three times and was evaporated under reduced pressure to give brown residues. The methanol extract (40 g) was subjected to vacuum liquid chromatography (VLC) using gradient elution system of Hexane: EtOAc. Thirty-nine fractions from two separate fractionations were obtained and spotted on TLC and similar profile was pooled to yield four major fractions. Further purification of fraction 4 by radial chromatography (silica gel, $\left.\mathrm{CHCl}_{3}: \mathrm{MeOH}\right)$ yielded compound $1(1.21 \mathrm{mg})$. Compound 2 and 3 also were obtained from radial chromatography.

\section{Results and Discussion}

Three flavonol glycosides isolated from the flower of Calliandra surinamensis were identified as 3-Orhamnosylkaempferol, 3-O-rhamnosylmyricetin and myricetin-3-O-heptoseptanoside (Figure 1).

\section{3-O-rhamnosylkaempferol (1)}

Yellow solid. MS m/z: 432, $\mathrm{C}_{21} \mathrm{H}_{20} \mathrm{O}_{10}$. UV $\lambda_{\max } \mathrm{nm}(\mathrm{MeOH}) 265$ and 342. IR $v_{\max }(\mathrm{KBr}): 1675$ and $3197 \mathrm{~cm}^{-1}$. For ${ }^{1} \mathrm{H}$ NMR and ${ }^{13} \mathrm{C}$ NMR data, see Table 1 .

Compound 1 was obtained as yellow solid and the mass spectral of the data gave a molecular weight of $\mathrm{C}_{21} \mathrm{H}_{20} \mathrm{O}_{10}$ corresponding to 21 carbon in ${ }^{13} \mathrm{C}$ NMR spectral data. ${ }^{1} \mathrm{H}$ NMR spectra of compound 1 showed signals for aromatic hydrogen at $\delta_{\mathrm{H}} 6.39(\mathrm{~d}, \mathrm{~J}=2.1)$ and $6.21(\mathrm{~d}, \mathrm{~J}=2.1)$ indicated $\mathrm{H}-6$ and $\mathrm{H}-8$, respectively at ring A of the flavonol skeleton. The ortho-coupled hydrogen at signal $\delta_{\mathrm{H}} 7.79(\mathrm{~d}, \mathrm{~J}=9.0)$ and $6.96(\mathrm{~d}, \mathrm{~J}=9.0)$ were assigned for $\mathrm{H}-2^{\prime} / 6^{\prime}$ and $\mathrm{H}-3^{\prime} / 5^{\prime}$, respectively at ring B. A signal at $\delta_{\mathrm{H}} 5.39(\mathrm{~d}, \mathrm{~J}=1.2)$ was assigned to the anomeric proton of $\mathrm{H}-1$ '”. One sugar moiety detected at C-3 of ring $\mathrm{C}$ assigned as rhamnose unit gave signals at $\delta 5.39(\mathrm{~d}, \mathrm{~J}=12), 4.24(\mathrm{dd}, \mathrm{J}=3.3$, 1.5), 3.73 (dd, $\mathrm{J}=9.3,3.6), 3.35(\mathrm{~d}, \mathrm{~J}=1.8), 3.31-3.33(\mathrm{~m})$ and $0.94(\mathrm{~d}, \mathrm{~J}=5.7)$. 
The APT NMR spectrum displayed 18 signals corresponding to 21 resonances. A signal at $\delta \mathrm{c} 178.20$ was appointed to carbonyl carbon $(\mathrm{C}=\mathrm{O})$ attached to oxygen at $\mathrm{C}-4$ whereas other signals at $\delta \mathrm{c} 98.42,93.34,115.11$ and 130.50 were corresponded to quaternary carbon attached to $\mathrm{OH}$ at C-6, C-8, C-3'/5' and C-2'/6', respectively. Additional of one rhamnose unit at C-3 of ring $\mathrm{C}$ was proved by signals at $\delta \mathrm{c} 102.09,70.51,70.63,71.76,70.70$ and 16.24 . This compound was previously isolated from the leaves of Schima wallichii and was reported to have potential for anticancer therapeutics [7].

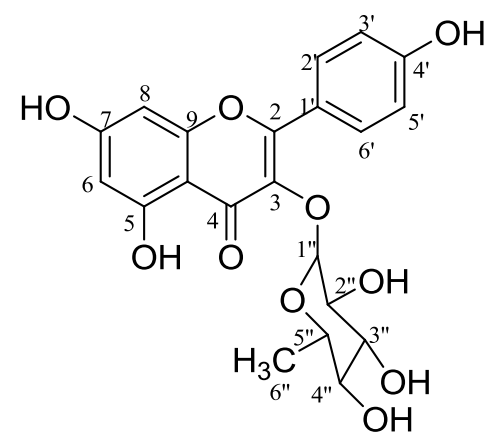

1

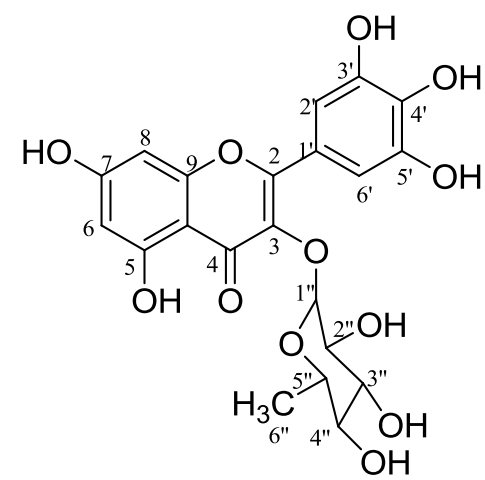

2<smiles>[CH2][C@H]1O[C@H](Oc2c(-c3cc(O)c(O)c(O)c3)oc3cc(O)cc(O)c3c2=O)[C@H](O)[C@@H](O)[C@@H](CO)[C@@H]1O</smiles>

3

Figure 1. Structures of compound 1-3

\section{3-O-rhamnosylmyricetin (2)}

Mass Spectrum m/z: 464, $\mathrm{C}_{21} \mathrm{H}_{20} \mathrm{O}_{12}$. UV $\lambda_{\max } \mathrm{nm}(\mathrm{MeOH}) 258,302$ and 352. IR $v_{\max }(\mathrm{KBr}): 1678$ and $3186 \mathrm{~cm}^{-1}$. For ${ }^{1} \mathrm{H}$ NMR and ${ }^{13} \mathrm{C}$ NMR data, see Table 1.

Compound 2 was obtained as yellow solid. The mass spectral of the data exhibit an $\mathrm{M}+$ at $\mathrm{m} / \mathrm{z} 464$, corresponding to molecular weight $\mathrm{C}_{21} \mathrm{H}_{20} \mathrm{O}_{12}$. Its ${ }^{1} \mathrm{H}$ NMR and ${ }^{13} \mathrm{C}$ NMR spectral data for 2 were closely related to compound $\mathbf{1}$ except that the AA'BB'-type coupling system in the B-ring of 1, was replaced by an AB-type coupling system in Bring for 2 . The ${ }^{13} \mathrm{C}$ NMR spectrum exhibited 16 signals corresponding to 17 carbon resonances. Signals at $\delta_{\mathrm{C}} 178.24$ was appointed to carbonyl carbon attached to oxygen (C-4) whereas other signals at $\delta_{\mathrm{C}} 145.01$ and $\delta_{\mathrm{C}} 148.40$ were corresponded to a quarternary carbon attached to $\mathrm{OH}$ at C-3' and C-5' respectively. Rhamnose was presence at C-3, $\left[\delta_{\mathrm{C}} 102.1,70.4,70.6,71.8,70.6,16.25 \mathrm{ppm}\right]$ as similar to compound 1 . This compound was isolated from the leaves of Myrica rubra and showed good anti-inflammatory activity [8]. 
Siti Muhayyah et al: THREE FLAVONOL GLYCOSIDES FROM Calliandra surinamensis Benth

Myricetin-3-O-heptoseptanoside (3)

Mass Spectrum m/z: 508, $\mathrm{C}_{23} \mathrm{H}_{24} \mathrm{O}_{13}$. UV $\lambda_{\max }$ nm (MeOH) 245 and 252. IR $v_{\max }(\mathrm{KBr}): 1679$ and $3174 \mathrm{~cm}^{-1}$ For ${ }^{1} \mathrm{H}$ NMR and ${ }^{13} \mathrm{C}$ NMR data, see Table 1.

Compound 3 was obtained as pale yellow solid. The mass spectral of the data exhibit an $\mathrm{M}+$ at $\mathrm{m} / \mathrm{z}$, corresponding to molecular weight $\mathrm{C}_{23} \mathrm{H}_{24} \mathrm{O}_{13}$. Compound 3 gave the ${ }^{1} \mathrm{H}$ NMR and ${ }^{13} \mathrm{C}$ NMR spectra shown in Table 1 , show the aglycone moiety at signal $\delta 6.79(\mathrm{~d}, \mathrm{~J}=1.8), 6.92(\mathrm{~d}, \mathrm{~J}=2.1), 7.92(\mathrm{dd}, \mathrm{J}=2.1,16.8)$ and $7.48(\mathrm{~d}, \mathrm{~J}=8.4)$. The APT NMR spectrum exhibited 18 signals corresponding to 21 resonances. Signals at $\delta_{\mathrm{C}} 179.2$ was appointed to carbonyl carbon attached to oxygen (C-4) whereas other signals at $\delta_{\mathrm{C}} 146.0$ and $\delta_{\mathrm{C}} 149.3$ were corresponded to a quarternary carbon attached to $\mathrm{OH}$ at C-3' and C-5' respectively. Additional of one sugar moiety at C-3 was confirmed with extra signals detected at $\delta_{\mathrm{C}} 103.1,71.5,72.9,73.4,64.0,71.6,71.7$ and 17.2. Thus, compound 3 was determined to be myricitrin-3-O-heptoseptanoside and this is the first report on the isolation of this constituent.

Table 1. Spectroscopic data ( ${ }^{1} \mathrm{H}$ NMR and ${ }^{13} \mathrm{C}$ NMR) for compounds 1-3

\begin{tabular}{|c|c|c|c|c|c|c|}
\hline \multirow{2}{*}{ Position } & \multicolumn{2}{|l|}{1} & \multicolumn{2}{|l|}{2} & \multicolumn{2}{|l|}{3} \\
\hline & $\delta_{\mathrm{H}}(\mathrm{Hz})$ & $\delta_{\mathrm{C}}(\mathrm{ppm})$ & $\delta_{\mathrm{H}}(\mathrm{Hz})$ & $\delta_{\mathrm{C}}(\mathbf{p p m})$ & $\overline{\delta_{\mathrm{H}}(\mathrm{Hz})}$ & $\delta_{\mathrm{C}}(\mathrm{ppm})$ \\
\hline 2 & - & 161.82 & - & 161.81 & - & 161.66 \\
\hline 3 & - & 134.80 & - & 134.82 & - & 135.86 \\
\hline 4 & - & 178.20 & - & 178.24 & - & 179.26 \\
\hline 5 & - & 164.50 & - & 164.47 & - & 165.43 \\
\hline 6 & $6.21(\mathrm{~d}, \mathrm{~J}=2.1)$ & 98.42 & $6.15(\mathrm{~d}, \mathrm{~J}=2.1)$ & 98.39 & $6.22(\mathrm{~d}, \mathrm{~J}=1.8)$ & 99.45 \\
\hline 7 & - & 164.50 & - & 164.47 & - & 162.79 \\
\hline 8 & $6.39(\mathrm{~d}, \mathrm{~J}=2.1)$ & 93.34 & $6.32(\mathrm{~d}, \mathrm{~J}=2.1)$ & 93.29 & $6.39(\mathrm{~d}, \mathrm{~J}=2.1)$ & 94.35 \\
\hline 9 & - & 157.14 & - & 157.12 & - & 158.13 \\
\hline 10 & - & 104.51 & - & 104.48 & - & 105.54 \\
\hline $1^{\prime}$ & - & 121.21 & - & 121.54 & - & 122.62 \\
\hline $2^{\prime}$ & $7.79(\mathrm{~d}, \mathrm{~J}=9.0)$ & 130.50 & $7.28(\mathrm{dd}, \mathrm{J}=1.8,12.9)$ & 115.50 & $7.92(\mathrm{~d}, \mathrm{~J}=7.8)$ & 116.24 \\
\hline $3^{\prime}$ & $6.96(\mathrm{~d}, \mathrm{~J}=9.0)$ & 115.11 & - & 145.01 & - & 146.00 \\
\hline $4^{\prime}$ & - & 160.18 & - & 157.91 & - & 158.92 \\
\hline $5^{\prime}$ & $6.96(\mathrm{~d}, \mathrm{~J}=9.0)$ & 115.11 & - & 148.40 & - & 149.38 \\
\hline $6^{\prime}$ & $\begin{array}{c}7.79(\mathrm{~d}, \mathrm{~J}=9.0) \\
\text { rhamnose }\end{array}$ & 130.50 & $\begin{array}{c}6.86(\mathrm{~d}, \mathrm{~J}=8.1) \\
\text { rhamnose }\end{array}$ & 114.95 & $\begin{array}{c}6.94(\mathrm{~d}, \mathrm{~J}=8.4) \\
\text { heptoseptanoside }\end{array}$ & 115.39 \\
\hline $1^{\prime \prime}$ & $5.39(\mathrm{~d}, \mathrm{~J}=1.2)$ & 102.09 & $5.29(\mathrm{~d}, \mathrm{~J}=1.2)$ & 102.13 & $5.37(\mathrm{~s})$ & 103.15 \\
\hline $2^{\prime \prime}$ & $4.24(\mathrm{dd}, \mathrm{J}=3.3,1.5)$ & 70.51 & $4.16(\mathrm{~m})$ & 70.49 & $4.25(\mathrm{~s})$ & 71.52 \\
\hline $3 "$ & $3.73(\mathrm{dd}, \mathrm{J}=9.3,3.6)$ & 70.63 & $3.71(\mathrm{dd}, \mathrm{J}=3.3,9.3)$ & 70.63 & $3.33(\mathrm{~s})$ & 72.90 \\
\hline $4 "$ & $3.35(\mathrm{~d}, \mathrm{~J}=1.8)$ & 71.76 & $3.24(2 \mathrm{H}$, complex $)$ & 71.83 & $3.61(\mathrm{dd}, \mathrm{J}=6.9)$ & 73.47 \\
\hline $5^{\prime \prime}$ & $3.31-3.33(\mathrm{~m})$ & 70.70 & $3.24(2 \mathrm{H}$, complex $)$ & 70.68 & $3.61(\mathrm{dd}, \mathrm{J}=6.9)$ & 64.05 \\
\hline $6^{\prime \prime}$ & $0.94(\mathrm{~d}, \mathrm{~J}=5.7)$ & 16.24 & $0.89(\mathrm{~d}, \mathrm{~J}=6.0)$ & 16.25 & $4.25(\mathrm{~s})$ & 71.63 \\
\hline $7 "$ & & & & & $3.78(\mathrm{~d}, \mathrm{~J}=3.0)$ & 71.77 \\
\hline $8^{\prime \prime}$ & & & & & $0.97(\mathrm{~d}, \mathrm{~J}=6.0)$ & 17.26 \\
\hline
\end{tabular}




\section{Conclusion}

Three flavonol glycoside compounds identified as 3-O-rhamnosylkaempferol (1), 3-O-rhamnosylmyricetin (2) and myricetin-3-O-heptoseptanoside (3) were successfully isolated from the flower of Calliandra surinamensis.

\section{Acknowledgement}

The authors would like to thank Institute of Graduate Studies (IGS) of UiTM under the Graduate Service Scheme and Conference Support Fund (IGS/JTA/FUND/2012(1)) and Faculty of Applied Sciences, Universiti Teknologi MARA for financing this research project.

\section{References}

1. Allen, O.N and Allen, E.K. (1981). Book: The leguminosae, a source book of characteristics, uses and nodulation, pp. $125-126$.

2. Koji, Y., Kazuyoshi, Y., Atsushi, H. and Tomio, N. (2006). A blood glucose increase inhibitor prepared from Calliandra haematocephala (Calliandra, Leguminosae) leaf extract. Japan. Kokai Tokyo Koho, JP 2006232750 A 20060907.

3. Irabor, E. E. I, Falodun, A., Obasuyi, O., Ofoegbu, C. O., Abiodun, S. O. and Umujeyan, K. (2007). Antimicrobial evaluation of methanolic extract of calliandra surinamensis on some pathogenic organism. Acta Poloniae Pharmaceutica-Drug Research, 63(5): 449 - 451.

4. Camazine, S. and Robert, A. (1980). A study of ethnobotany of the Zuni Indians of New Mexico. Journal of Ethnopharmacology, 2: $365-388$.

5. Falodun, A. and Qiu, S. (2010). Isolation and characterization of chemical principles from rootbark of Calliandra surinamensis. Nigerian Journal of Biochemistry and Molecular Biology, 25(2): 17 - 22.

6. Sofowora, A. (1984). A screening plants for bioactive agents: In medicinal plants and traditional medicine in Africa. Spectrum Books Limited. $1^{\text {st }}$ edition. John Wiley and Sons, London.

7. Diantini, A., Subarnas, A., Lestari, K., Halimah, E., Susilawati, Y., Supriyatna., Julaeha, E., Achmad, T. H., Suradji, E. W., Yamazaki, C., Kobayashi, K., Koyama, H. and Abdulah, R. (2012). Kaempferol-3-orhamnoside isolated from the leaves of Schima wallichii Korth. Inhibits MCF-7 breast cancer cell proliferation through activation of the caspase cascade pathway. Oncology Letters, 3: 1069 - 1072.

8. Kim, H. H., Kim, D. H., Kim, M. H., Oh, M. H., Kim, S. R., Park, K. J. and Lee, M. W. (2013). Flavonoid constituents in the leaves of Myrica rubra Sieb. et zucc. with anti-inflammatory activity. Achieves of Pharmacological Research, 36(12): 1533 - 1540. 